
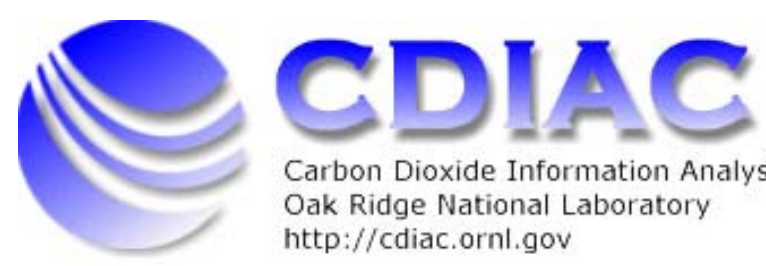

Carbon Dioxide Information Analysis Center

Oak Ridge National Laboratory

http://cdiac.ornl.gov

\title{
Recent Greenhouse Gas Concentrations
}

T.J. Blasing

DOI: 10.3334/CDIAC/atg.032

Updated July 2009

Gases typically measured in parts per million (ppm), parts per billion (ppb) or parts per trillion (ppt) by volume are presented separately to facilitate comparison of numbers. Global Warming Potentials (GWPs) and atmospheric lifetimes are from the Intergovermental Panel on Climate Change (IPCC, 2007, Table 2.14), except for the atmospheric lifetime of carbon dioxide (CO2) which is explained in footnote 4. Additional material on greenhouse gases can be found in CDIAC's Reference Tools. To find out how CFCs, HFCs, HCFCs, and halons are named, see Name that compound: The numbers game for CFCs, HFCs, HCFCs, and Halons.

Sources of the current atmospheric concentrations are given in the footnotes. The concentrations given are mostly derived from data available via the CDIAC Web pages; many corresponding links are given in the footnotes below. These data are contributed to CDIAC by various investigators, and represent considerable effort on their part. We ask as a basic professional courtesy that you acknowledge the primary sources when you refer to data from any of these sites. Guidelines for proper acknowledgment are found at each link, except for the ALE/GAGE/AGAGE database where acknowledgment guidelines are given in the "readme" files; links to those "readme" files are given in footnote 9, below.

\begin{tabular}{|c|c|c|c|c|c|}
\hline GAS & $\begin{array}{l}\text { Pre-1750 } \\
\text { tropospheric } \\
\text { concentration } 1\end{array}$ & $\begin{array}{l}\text { Current } \\
\text { tropospheric } \\
\text { concentration }\end{array}$ & $\begin{array}{l}\text { GWP3 }(100-y r \\
\text { time } \\
\text { horizon })\end{array}$ & $\begin{array}{l}\text { Atmospheric } \\
\text { lifetime }^{4} \text { (years) }\end{array}$ & $\begin{array}{l}\text { Increased } \\
\text { radiative } \\
\text { forcing } 5 \\
\left(\mathrm{~W} / \mathrm{m}^{2}\right)\end{array}$ \\
\hline \multicolumn{6}{|c|}{ Concentrations in parts per million (ppm) } \\
\hline Carbon dioxide (CO2) & $280^{6}$ & $384.8^{7}$ & 1 & $\sim 100^{4}$ & 1.66 \\
\hline \multicolumn{6}{|c|}{ Concentrations in parts per billion (ppb) } \\
\hline Methane $\left(\mathrm{CH}_{4}\right)$ & $700^{8}$ & $1857^{9} / 1735^{9}$ & 25 & $12^{4}$ & 0.48 \\
\hline Nitrous oxide $\left(\mathrm{N}_{2} \mathrm{O}\right)$ & $270^{10}$ & $3219 / 320^{9}$ & 298 & 1144 & 0.16 \\
\hline $\begin{array}{l}\text { Tropospheric ozone } \\
\text { (O3) }\end{array}$ & $25^{1}$ & $34^{4,1}$ & n.a. ${ }^{4}$ & hours-days & $0.35^{4}$ \\
\hline \multicolumn{6}{|c|}{ Concentrations in parts per trillion (ppt) } \\
\hline $\begin{array}{l}\text { CFC-11 } \\
\text { (trichlorofluoromethane) } \\
\left(\mathrm{CCl}_{3} \mathrm{~F}\right)\end{array}$ & zero & $246^{9} / 243^{9}$ & 4,750 & 45 & 0.063 \\
\hline $\mathrm{CFC}-12\left(\mathrm{CCl}_{2} \mathrm{~F}_{2}\right)$ & zero & $5419 / 5379$ & 10,900 & 100 & 0.17 \\
\hline
\end{tabular}




\begin{tabular}{|c|c|c|c|c|c|}
\hline $\mathrm{CF}-113\left(\mathrm{CCl}_{2} \mathrm{FFClF}_{2}\right)$ & zero & $779 / 779$ & 6,130 & 85 & 0.024 \\
\hline $\mathrm{HCFC}-22\left(\mathrm{CHClF}_{2}\right)$ & zero & $1979 / 1759$ & 1,810 & 12 & 0.033 \\
\hline $\mathrm{HCFC}-141 \mathrm{~b}\left(\mathrm{CH}_{3} \mathrm{CCl}_{2} \mathrm{~F}\right)$ & zero & $219 / 17^{9}$ & 725 & 9.3 & 0.0025 \\
\hline $\mathrm{HCFC}-142 \mathrm{~b}\left(\mathrm{CH}_{3} \mathrm{CClF}_{2}\right)$ & zero & $20^{9} / 17^{9}$ & 2,310 & 17.9 & 0.0031 \\
\hline Halon 1211 (CBrCIF 2$)$ & zero & $4.4^{9} / 4.2^{9}$ & 1,890 & 16 & 0.001 \\
\hline Halon 1301 (CBrCIF3) & zero & $3.29 / 3.19$ & 7,140 & 65 & 0.001 \\
\hline $\mathrm{HFC}-134 \mathrm{a}\left(\mathrm{CH}_{2} \mathrm{FCF}_{3}\right)$ & zero & $499 / 419$ & 1,430 & 14 & 0.0055 \\
\hline $\begin{array}{l}\text { Carbon tetrachloride } \\
\left(\mathrm{CCl}_{4}\right)\end{array}$ & zero & $909 / 889$ & 1,400 & 26 & 0.012 \\
\hline $\begin{array}{l}\text { Methyl chloroform } \\
\left(\mathrm{CH}_{3} \mathrm{CCl}_{3}\right)\end{array}$ & zero & $12.7^{9} / 12.19$ & 146 & 5 & 0.0011 \\
\hline Sulfur hexafluoride (SF6) & zero & $6.40^{9,11 / 6.039,11}$ & 22,800 & 3200 & 0.0029 \\
\hline Other Halocarbons & zero & $\begin{array}{l}\text { Varies by } \\
\text { substance }\end{array}$ & & & $\begin{array}{c}\text { collectively } \\
0.021\end{array}$ \\
\hline
\end{tabular}

\section{Footnotes}

1. Pre- 1750 concentrations of $\mathrm{CH}_{4}, \mathrm{~N}_{2} \mathrm{O}$ and current concentrations of $\mathrm{O}_{3}$, are taken from Table 4.1 (a) of the IPCC Intergovernmental Panel on Climate Change), 2001. Following the convention of IPCC (2001), inferred global-scale trace-gas concentrations from prior to 1750 are assumed to be practically uninfluenced by human activities such as increasingly specialized agriculture, land clearing, and combustion of fossil fuels. Preindustrial concentrations of industrially manufactured compounds are given as zero. The short atmospheric lifetime of ozone (hours-days) together with the spatial variability of its sources precludes a globally or vertically homogeneous distribution, so that a fractional unit such as parts per billion would not apply over a range of altitudes or geographical locations. Therefore a different unit is used to integrate the varying concentrations of ozone in the vertical dimension over a unit area, and the results can then be averaged globally. This unit is called a Dobson Unit (D.U.), after G. M. B. Dobson, one of the first investigators of atmospheric ozone. A Dobson unit is the amount of ozone in a column which, unmixed with the rest of the atmosphere, would be 10 micrometers thick at standard temperature and pressure.

2. Because atmospheric concentrations of most gases tend to vary systematically over the course of a year, figures given represent averages over a 12-month period for all gases except ozone $\left(\mathrm{O}_{3}\right)$, for which a current global value has been estimated (IPCC, 2001, Table 4.1a). Monthly CO2 averages for July 2007 through June 2008 are taken from the National Oceanic and Atmospheric Administration, Earth System Research Laboratory, web site: www.esrl.noaa.gov/gmd $\angle \mathrm{ccgg} /$ trends maintained by Dr. Pieter Tans. For other chemical species, the values given represent averages of the 12 most recent months for which AGAGE data are available (currently October 2006-September 2007). These data are found on the CDIAC AGAGE web site: http://cdiac.ornl.gov/ndps/alegage.html or the AGAGE home page: http://agage.eas.gatech.edu.

3. The Global Warming Potential (GWP) provides a simple measure of the radiative effects of emissions of various 
greenhouse gases, integrated over a specified time horizon, relative to an equal mass of $\mathrm{CO}_{2}$ emissions. The GWP with respect to $\mathrm{CO}_{2}$ is calculated using the formula:

$$
\mathbf{G W P}=\frac{\int_{T R}^{T H} \mathbf{a}_{i} \mathbf{C}_{i}(t) d t}{\int_{T R}^{T H} \mathbf{a}_{\mathrm{CO}_{2}} \mathbf{C}_{\mathrm{CO}}(t) d t}
$$

where $a_{i}$ is the instantaneous radiative forcing due to the release of a unit mass of trace gas, $i$, into the atmosphere, at time $\mathrm{TR}, \mathrm{Ci}$ is the amount of that unit mass remaining in the atmosphere at time, t, after its release and TH is TR plus the time horizon over which the calculation is performed (100 years in this table).

Formula adapted from page 210 of IPCC (2007).

4. The atmospheric lifetime is used to characterize the decay of an instanenous pulse input to the atmosphere, and can be likened to the time it takes that pulse input to decay to $0.368(1 / \mathrm{e})$ of its original value. The analogy would be strictly correct if every gas decayed according to a simple expotential curve, which is seldom the case. For example, $\mathrm{CH}_{4}$ is removed from the atmosphere by a single process, oxidation by the hydroxyl radical $(\mathrm{OH})$, but the effect of an increase in atmospheric concentration of $\mathrm{CH}_{4}$ is to reduce the $\mathrm{OH}$ concentration, which, in turn, reduces destruction of the additional methane, effectively lengthening its atmospheric lifetime. An opposite kind of feedback may shorten the atmospheric lifetime of $\mathrm{N}_{2} \mathrm{O}$ (IPCC 2007, Section 2.10.3). For CO2 the specification of an atmospheric lifetime is complicated by the numerous removal processes involved, which necessitate complex modeling of the decay curve. Because the decay curve depends on the model used and the assumptions incorporated therein, it is difficult to specify an exact atmospheric lifetime for $\mathrm{CO}_{2}$. Accepted values range around 100 years. Amounts of an instantaneous injection of $\mathrm{CO}_{2}$ remaining after 20, 100, and 500 years, used in the calculation of the GWPs in IPCC (2007), may be calculated from the formula given in footnote $a$ on page 213 of that document. The above-described processes are all accounted for in the derivation of the atmospheric lifetimes in the above table, taken from IPCC (2007). The short lifetime of ozone (hours-days) precludes a meaningful calculation of global warming potential on the time horizons (20, 100, and 500 years) listed in IPCC (2007). The current estimate of the globally averaged radiative forcing for tropospheric ozone is taken from the fourth column (most recent estimates) of Table 2.12 on page 204 of IPCC (2007). Note also in the same column that changes in stratospheric ozone have resulted in a decrease in radiative forcing of $0.05 \mathrm{~W} / \mathrm{m}^{2}$.

5. Changes (since 1750) in radiative forcing represent changes in the rate per square meter, at which energy is supplied to the atmosphere below the stratosphere. Greenhouse gases, aerosols, and changes in the sun's energy output may each be involved. Note from IPCC 2007 (Figure SPM.2) that aerosols frequently have the effect of decreasing this radiative forcing. Energy is measured in Joules; the rate at which it is made available is in Joules/second, or Watts; hence, radiative forcing is measured in Watts per square meter $\left(\mathrm{W} / \mathrm{m}^{2}\right)$. Numerical values of the increased radiative forcings for all species listed in this table, except for ozone (O3) and halons 1211 and 1301, are given for 2005 in Table 2.1 of IPCC (2007). Radiative forcing for tropospheric ozone is given in Figure SPM.2 and Table 2.12 of IPCC (2007). The "current" value refers to a global average. Note that the change in radiative forcing due to stratospheric ozone is negative $0.05 \mathrm{~W} / \mathrm{m}^{2}$. Note also the uncertainty ranges given. Forcings for halons 1211 and 1301 were each estimated as their radiative efficiency multiplied by their 2005 concentration, so as to be consistent with the 2005 concentrations for the other species given in IPCC (2007). This calculation assumes that the radiative efficiencies have not changed with time, for these small concentrations (cf. Mitchell 
1989). The sum of radiative forcings for all halocarbons is 0.337 , in accord with Table 2.1 of IPCC (2007). All forcings are given for year 2005 (IPCC, 2007) and are approximately current; for updates, see the NOAA Annual Greenhouse Gas Index at: http://www.esrl.noaa.gov/gmd/aggi/.

6. The value given by IPCC 2001, page 185, is $280 \pm 10 \mathrm{ppm}$. This is supported by measurements of CO2 in old, confined, and reasonably well-dated air. Such air is found in bubbles trapped in annual layers of ice in Antarctica, in sealed brass buttons on old uniforms, airtight bottles of wine of known vintage, etc. Additional support comes from well-dated carbon-isotope signatures, for example, in annual tree rings. Estimates of "pre-industrial" $\mathrm{CO}_{2}$ can also be obtained by first calculating the ratio of the recent atmospheric $\mathrm{CO}_{2}$ increases to recent fossil-fuel use, and using past records of fossil-fuel use to extrapolate past atmospheric $\mathrm{CO}_{2}$ concentrations on an annual basis. Estimates of "pre-industrial" $\mathrm{CO}_{2}$ concentrations obtained in this way are higher than those obtained by more direct measurements; this is believed to be because the effects of widespread land clearing are not accounted for. Ice-core data provide records of earlier concentrations. For concentrations back to about 1775, see A. Neftel et al. http://cdiac.ornl.gov/trends/co2/siple.html. The record derived from the DSS Antarctic ice core indicates an average concentration of 280.05 ppm from 1000-1750 C.E. For over 400,000 years of ice-core record from Vostok, see J. M. Barnola et al.. For ice-core records extending over 650,000 years back in time, see Siegenthaler et al. (2005).

7. Recent $\mathrm{CO}_{2}$ concentration $(384.8 \mathrm{ppm})$ is the 2008 average taken from globally averaged marine surface data given by the National Oceanic and Atmospheric Administration Earth System Research Laboratory, web site: http://www.esrl.noaa.gov Lgmd/ccgg/trends/index.html\#global. Please read the material on that web page and reference Dr. Pieter Tans when citing this average (Dr. Pieter Tans, NOAA/ESRL http://www.esrl.noaa.gov/gmd/ccgg/trends). The 2008 average derived from in-situ data at the four "baseline" stations (Point Barrow, Alaska, Mauna Loa, Hawaii, American Samoa, and the South Pole) is 384.9 ppm which is only 0.1 ppm greater than the value obtained from the marine surface observations, and 0.1 ppmv is the error term given by Dr. Tans so the two values for 2008 are virtually identical. The oft-cited Mauna Loa average for 2008 is 385.5, which is a good approximation although 0.6-0.7 ppm higher than the spatial averages given above. Refer to http://www.esrl.noaa.gov/gmd/ccgg/trends for records back to the late 1950s.

8. Pre-industrial concentrations of $\mathrm{CH} 4$ are evident in the "1000-year" ice-core records in CDIAC's Trends Online http://cdiac.ornl.gov/trends/atm_meth/lawdome_meth-graphics.html. However, those values need to be multiplied by a scaling factor of 1.0119 to make them compatible with the AGAGE measurements of current methane concentrations, which have already been adjusted to the Tohoku University scale. Ten thousand-year records of $\mathrm{CH}_{4}, \mathrm{CO}_{2}$ and $\mathrm{N}_{2} \mathrm{O}$, from ice-core data, are also presented graphically in IPCC 2007, (Figure SPM.1).

9. The first value in a cell represents Mace Head, Ireland, a mid-latitude Northern-Hemisphere site, and the second value represents Cape Grim, Tasmania, a mid-latitude Southern-Hemisphere site. "Current" values given for these gases are annual arithmetic averages based on monthly background concentrations for October 2006 through September 2007. The SF6 values are from the AGAGE gas chromatography - mass spectrometer (gc-ms) Medusa measuring system. Source: Advanced Global Atmospheric Gases Experiment (AGAGE) data posted on CDIAC web site at: $\underline{\text { http://cdiac.ornl.gov }}$ /ftp/ale_gage_Agage/. These data are compiled from data on finer time scales in the ALE/GAGE/AGAGE database (R. 
Prinn et al., 2008). These data represent the work of several investigators at various institutions; guidelines on citing the various parts of the AGAGE database are found at the link above or at http://cdiac.agage.eas.gatech.edu/data_archive Lagage/readme within the ALE/GAGE/AGAGE database, which can also be accessed via anonymous ftp.

10. Source: IPCC (2007). The pre-1750 value for $\mathrm{N}_{2} \mathrm{O}$ is consistent with ice-core records from 10,000 B.C.E. through 1750 C.E. shown graphically in figure SPM.1 on page 3.

11. For SF6 data from January 2004 onward see http://cdiac.ornl.gov/ftp/ale_gage_Agage/AGAGE/gc-ms-medusa /monthly/. For data from 1995 through 2004, see the National Oceanic and Atmospheric Administration (NOAA), Halogenated and other Atmospheric Trace Species (HATS) site at: http://www.esrl.noaa.gov/gmd/hats/airborne Lindex.html. Concentrations of $\mathrm{SF}_{6}$ from 1970 through 1999, obtained from Antarctic firn air samples, can be found in $\underline{\mathrm{W}}$. T. Sturges et al.

\section{References}

- IPCC (Intergovernmental Panel on Climate Change), 2007. Climate Change 2007: The Physical Science Basis, Contribution of Working Group I to the Fourth Assessment Report of the Intergovernmental Panel on Climate Change (Solomon, S., D. Qin, M. Manning, Z. Chen, M,. Marquis, K.B. Averyt, M. Tignor and H.L. Miller (eds.)]. Cambridge University Press, Cambridge United Kingdom and New York, NY, USA, 996 pp.

- IPCC 2001. Climate Change 2001: The Scientific Basis. J. T. Houghton, Y. Ding, D. J. Griggs, M. Noguer, P. J. van der Linden, X. Dai, K. Maskell, and C. A. Johnson, (eds), Cambridge University Press, Cambridge, UK, 881 pp.

- Mitchell, J. F. B., 1989. The "greenhouse" effect and climate change. Reviews of Geophysics 27(1), 115-139.

- Siegenthaler U., et al. 2005. Stable Carbon-Cycle Climate Relationship during the late Pleistocene. Science 310 (1313). 